\title{
The problem of ethnocultural identity in the studies of symbolic interactionism
}

\section{El problema de la identidad etnocultural en los estudios del interaccionismo simbólico}

\author{
Lyudmila Redkina \\ redkina7@mail.ru \\ https://orcid.org/0000-0002-4201-8693 \\ Doctor of Pedagogy, Head of Department, Department of Pedagogy and Management \\ of Educational Institutions, V.I. Vernadsky Crimean Federal University, Russia. \\ Irina Zakiryanova \\ ariddsev@yandex.ru \\ https://orcid.org/0000-0001-7770-0986 \\ $\mathrm{PhD}$ in Pedagogy, Professor, Department of Foreign Languages, P.S. Nakhimov Black \\ Sea Higher Naval School, Russia. \\ Vladimir Vishnevsky \\ vmwbox@gmail.com \\ https://orcid.org/0000-0002-1471-7067 \\ $\mathrm{PhD}$ in Pedagogy, Associate professor, Department of Pedagogy and Management of \\ Educational Institutions, V.I. Vernadsky Crimean Federal University, Russia. \\ Tatiana Chernova \\ Tatyana_chernova55@mail.ru \\ https://orcid.org/0000-0003-0249-9813 \\ PhD student, Department of Pedagogy and Social Work, I.N. Ulyanov Ulyanovsk State \\ Pedagogical University, Russia.
}

\section{Abstract}

Recibido: 20/08/2

Aceptado: 29/10/21

The article addresses the problem of ethnocultural identity in the context of research by representatives of symbolic interactionism. The problem of ethnocultural identity acquires relevance in the epoch of globalisation, when the differences between nations and ethnosocial groups are erased, ignoring the folk traditions, customs, rituals, i.e. the historically and culturally established values that distinguish one nation from another, on the one hand, and enrich the multinational culture of their country, on the other hand. The purpose of the study is to reveal the conditions for the formation of ethnocultural identity and the factors influencing it. The works by G.H. Mead, C.H. Cooley, E. Goffman, J. Habermas and other authors were analysed within the framework of the research. The study 
revealed that the formation of ethnocultural identity involves assimilation of the values, norms, beliefs of "own" socio-cultural community, which is possible in the process of social interaction, in the course of meaningful communication in terms of symbolic interactionism.

Keywords: ethnocultural identity, formation of ethnocultural identity, symbolic interactionism, social interaction, interpersonal communication.

\section{Resumen}

El artículo aborda el problema de la identidad etnocultural en el contexto de la investigación de representantes del interaccionismo simbólico. El problema de la identidad etnocultural adquiere relevancia en la época de la globalización, cuando se borran las diferencias entre naciones y grupos etno-sociales, ignorando las tradiciones, costumbres, rituales populares, es decir, los valores histórica y culturalmente establecidos que distinguen a una nación de otra, en, por un lado, y enriquecer la cultura multinacional de su país, por otro. El propósito del estudio es revelar las condiciones para la formación de la identidad etnocultural y los factores que la influyen. Las obras de G.H. Mead, C.H. Cooley, E. Goffman, J. Habermas y otros autores fueron analizados en el marco de la investigación. El estudio reveló que la formación de la identidad etnocultural implica la asimilación de los valores, normas, creencias de la comunidad sociocultural "propia", lo cual es posible en el proceso de interacción social, en el curso de la comunicación significativa en términos de interaccionismo simbólico.

Palabras clave: identidad etnocultural, formación de identidad etnocultural, interaccionismo simbólico, interacción social, comunicación interpersonal.

\section{Introduction}

The process of search for ethnocultural identity in modern socio-cultural conditions requires philosophical, social and psychological justification. Nowadays of foremost importance is the problem of preservation of ethnocultural identity, the process of formation of ethnocultural identity, the correlation of individual and group components of ethnocultural identity in the context of social evolution. The research in this area was carried out actively by such representatives of symbolic interactionism as George Herbert Mead (1972), Charles Horton Cooley (1907, 1909), Erving Goffman (1961), Jürgen Habermas (1971).

The concept of symbolic interactionism is based on the premises that all forms of human interaction in the society suppose communication based on certain social symbols language, gestures, cultural symbols, intonation. It is through meaningful communication, i.e. interaction with the help of meaningful symbols of which the most important are contained in the language, that a person acquires identity, including ethnocultural identity. According to the concept of symbolic interactionism, the formation of man's ethnocultural identity in fact takes place in the situations of mutual, joint action with other people. The 
mechanism of ethnocultural identity formation is the result of correlation of two processes: a person's awareness of own "Self" as an object (i.e. how the others see this person) and one's "Self" as a subject (i.e. how a person sees himself). Ethnocultural identity, thus, being formed in the course of social interaction, is a person's holistic perception of himself $^{2}$ and the social environment. This understanding of ethnocultural identity as a certain entirety determines the individual's aspiration towards being able to perceive himself as an integral whole within a harmonious bond with the surrounding world, which contributes to the formation of positive ethnocultural identity.

Despite the fact that the role of symbols is substantial in the concept of symbolic interactionism, when the human behaviour in situations of social interaction and the whole range of social relations is conditioned by symbolic, denotative interpretation of such situations and relations, nevertheless, an important fact is that symbolic interactionism, that raised the issue of social determinants of interaction and of its significant role in the formation of human personality, makes it possible to consider the problem of ethnocultural identity from the position of active social interaction, since ethnocultural identity is realised through actions and interaction. Man's positive acceptance of himself as an integral part of his ethnos, being primarily expressed in ethnocultural identity, is exteriorised by his social actions and interaction.

Therefore, the purpose of this article is studying the problem of ethnocultural identity from the position of representatives of symbolic interactionism and identification of key factors contributing to the formation of ethnocultural identity on this basis. To pursue this goal, the following objectives were set: to study the theoretical aspects of the problem of ethnocultural identity in the scholarly works of adherents of symbolic interactionism and to identify the psychological conditions contributing to the formation of ethnocultural identity. The use of the concept of symbolic interactionism makes it possible to reveal the in-depth nature of integral interrelation and interdependence of socio-cultural and personal factors contributing to the formation of ethnocultural identity that is really significant in the context of interethnic relations in the multicultural space.

\section{Literature Review}

The problem of a person's ethnocultural identity in the contemporary world, being conditioned by search for vitally important determinants, value orientations in the conditions of modern socio-cultural transformations, has been a subject of research undertaken by a number of scientists: Andreeva, Bogomolova \& Petrovskaya (2002), Arutyunyan (2010), Parhomenko (2014), Skorodumova (2010), Tancheva (2017), Katartzi (2017). This enables the authors to consider the ethnocultural identity formation problem as a systemic personal characteristic in the context of integrity of man's personal development. 2 [hereinafter the use of masculine gender encompasses the feminine gender: he=she, his=her, him=her,
himself=herself - translator's note]. 
According to Eng \& Tram (2021) and Shastina, Shatunova, Bozhkova (2018), the formation of ethnocultural identity is influenced in the first place by the primary social group, namely, cultural socialisation in the family.

The interdependence of ethnocultural identity and the folk, ethnical, cultural sphere that form the environment for person's socialisation is discussed in the studies of: Markus \& Kitayama (1991), Adams \& Markus (2001), Hakim-Larson \& Menna (2016).

The ethnocultural identity raises a person's self-esteem, thus engendering positive psychological consequences, as discussed by Cast \& Burke (2002) and Shamionov (2014).

Of special interest is the study of ethnocultural identity formation issues in the context of symbolic interactionism that accentuates such factors as social interaction resulting in self-identification of a human subject as a member of a certain ethnocultural community, since ethnocultural identity is realised through social actions and interaction. Among the scholars exploring this domain are primarily: Mead (1972), Cooley $(1907,1909,1922)$, Goffman (1959, 1961, 1963), Habermas (1971, 1976, 1999, 2001, 2004), RomanucciRoss \& De Vos (1995), since their studies of the problem of man's self-identification in the process of social interaction served as a kind of impetus addressing the problem of ethnocultural identity as an integral part of social identity, revealing the conditions facilitating the formation of this systematically-, personally- and socially significant quality. A person builds his own life strategy, his stable and relatively predictable social interactions on the basis of his ethno-cultural identity, which contributes to constructive interethnic interaction in the conditions of multicultural space.

\section{Methodology}

The methodological basis of this study is represented by the ideas and conclusions concerning psychological conditions for formation of ethnocultural identity in terms of the concept of symbolic interactionism. To handle the objectives of the study, a number of theoretical research methods were used: analysis of psycho-pedagogical, sociological, philosophical literature on the problem in question; general scientific methods: analysis and synthesis, comparison and correlation of different approaches to the study of the problem of ethnocultural identity.

\section{Results and Discussion}

Mead (1972), exploring the problem of relationship between social determination and individual freedom, distinguishes between perceived and unconscious identity. Perceived identity manifests itself through cognitive processes, when an individual begins to reflect on himself and his behaviour. Unconscious identity is based on unconsciously accepted norms, values, attitudes, on the complex of expectations imposed by the ethno-social community to which a person belongs. The transition from unconscious to perceived identity takes place as a result of reflection. Thus, according to Mead (1972), a person, 
by reflecting about himself, perceives his identity. It is essential that this conceptualisation takes place by means of language in the course of social interaction (Arutyunyan, 2010). This means, in the context of the given research problem, that a person who has acknowledged his identity, his "Self" from the position of the characteristics accepted in his community, becomes able to define his place in the socio-cultural space, orientate himself freely in the surrounding world, construct his life activity in a due way, as well as his behaviour and relations with partners in interaction.

In accordance with the general characteristics of the interactionist school, ethnocultural identity is viewed as a social phenomenon formed in the course of social interaction. Ethnocultural identity is a holistic perception of one's self and the social world, therefore the structure of ethnocultural identity includes not just the cohesion of elements, but also connections between one's Self and the whole (Mead, 1972). Furthermore, ethnocultural identity is the result of communication with conjugate people which forms the role-play behaviour in this process. This means that man strives to achieve experience of himself as a whole in a harmonious conjunction with the world around, with his ethno-social community. The fundamental premise of this provision is that the formation of the reflexive ethno-social "Self" takes place in the process of interaction with other people. The ability to cognise oneself is formed in social life through the aspect designated by Mead (1972) as "assuming the role of the other" or "accepting the relation of others to oneself". The mediators in this process are meaningful other people (originally parents, close-minded friends and relatives). Talking of "generalised others", Mead (1972) means a complex of impersonal settings - norms and values of the society. The stages of accepting the role of someone other, of others, of generalised others reflect the phases of transforming a physiological organism into a reflexive ethno-social "Self".

Methodologically, this interpretation draws on James's (1920) division of the personality structure into metaphysical integrity (the soul) and functional identity ("one's Self") and the concept of "mirrored (reflected) Self" (Cooley, 1922).

In elucidating the social nature of the human self, Mead and Cooley followed James in concluding that it is interpersonal interaction that plays a crucial role in the formation of this self.

The man himself as a subject of this interaction is understood not as an abstract individual, but, according to Cooley (1922), as a "part of the social whole": "The Self is an active social force... Treating it apart from the society is blatant nonsense... There is not any meaning inherent in "Self" that would not have notional correlation with "You", "He" or "They". The "human nature" cannot be narrowed down to its biological substructure, the so-called set of "instincts, shapeless impulses, indefinable abilities", but is interpreted as a social substance that is "produced through simple forms of close, personal interaction". Personal interaction results in psychological correlation of the individual with the ethnic community with which he shares certain norms, values and attitudes (Cooley, 1922). 
According to Cooley (1922), a person perceives his own self through reflection in others. Therefore, it is of great importance how a person is perceived by the others, what ethnic community he is associated with. In the process of social interaction and communicating with others, we look into the others' perception of ourselves, like looking in a mirror, and judge ourselves by this reflection (Cooley, 1922). Mead (1972) also recognises that selfidentification of the individual, as a performer of a particular role, takes place through awareness and acceptance of perception of him by the others.

In addition, Cooley (in the 1920s) and Mead (in the 1930s) demonstrated that personal identity is not an a priori of human behaviour, but it emerges from properties generated in the course of social interaction ("social interaction"). Identity is fundamentally a social morphosis; one sees himself in the way he is seen by the others. In fact, "Self-identity" and "the Other" are fundamentally inseparable for Cooley and Mead. Identity is a generalised, integrated "Other".

One can conclude, based on the premises put forward by Cooley and Mead, that identity is not a property (i.e. something inherent in the individual), but a certain attitude. It is formed, gets established (or, on the contrary, is modified, transformed) only in the process of social interaction. This conclusion, in our view, correlates with the semantic field of ethnocultural identity in the sense that ethnic identity is most often formed not as a result of some national quality or a surname having an expressed ethnic imprint, but in the process of individual self-identification.

Cooley and Mead's ideas about the problem of identity, in particular ethnocultural identity, were synthesised in E. Goffman's "dramatic model” of social interaction. Goffman (1963) considers identity in the context of plurality of social roles.

Proceeding from Mead's (1972) provision on existence of two known types of identity socially predetermined identity and identity reflecting person's individual properties - I. Goffman (1963) distinguishes three types of identity:

1) social, involving typification of a person in terms of congeniality with other people, as based on the attributes of social community he belongs to;

2) personal, correlated with person's individual characteristics (unique phenotypic attributes of a person, on the one hand, and the unique combination of facts and dates of his life history);

3) "Self"-identity, i.e. a person's subjective perception of his life situation, his continuity and originality.

Social identity carries the greatest functional load. It represents a set of identities, i.e. social roles, "masks" that constitute the content and forms of human behaviour. Goffman (1963) defines personal identity as a social phenomenon, since the perception of personal identity takes place on the condition that the information about the facts of a person's life - on the previous experience of interaction with other people, on the person's environment - is known to his interaction partner. According to Goffman's (1963) 
dramaturgical approach focused on the idea of drawing an analogy between the social world and the theatre world, where the social roles are comparable to theatrical roles played in order to produce a certain impression on the communication participants and to yield response to their expectations, the prevailing role of the social setting makes a person play roles continually, to interpret situations with regard for established limits, to build strategies for due adaptation and achievement of desired goals.

Goffman (1963) accepts James's (1920) concept of social personality as a starting point in his analysis of interactive microsystems. Goffman (1963) is willing to study these masks, the guise of social actors, that eventually fuse with the face and become a more authentic "Self" than the "Self" imagined and sought by these people. The mask, the role is justified by life. A person's conception of his role becomes a second nature and a part of the personality. When Goffman (1963) talks occasionally about "the mismatch between our natural self and our social self' he contemplates about this not in terms of contraposition of the biologically and socially nurtured identity, but rather from the position of different social demands posed in different social settings. Some social environments expect certain "bureaucratisation of spirit" and discipline of action from us, regardless of bodily condition, while the others allow for impulsiveness and dependence of our performance on ill-health (Goffman, 1959).

Goffman (1959) defines ethnocultural identity as the one that is "socially created, socially maintained and socially transformed". It is in social micro-entities that a certain kind of activity takes place in terms of managing impressions and assessing situations. He proceeds from the fact that the individual constructs his own ethnocultural identity from the material conceived by the culture in which he lives.

Abstracting from the holistic personal characteristics of the individual, Goffman considers him only as a bearer of various roles set outwardly, unrelated, not connected with one's personal features or one's activities or with some objective socio-historical conditions. At the same time, Goffman believes that man in the process of social interaction is capable not only to view himself through the eyes of his partner, but also to adjust own behaviour in accordance with the expectations of others in order to create most favourable impression of himself and gain maximum benefit from this interaction (Andreeva et al, 2002). Stated differently, Goffman considers social interaction partners in terms of how they position themselves before each other in order to set the frame of interaction (own and reciprocal).

Developing the idea of the ways in which ethnocultural identity and the surrounding world ("Umwelt") interact, Goffman (1959) suggests that it is the surrounding world that is the basis for the development of ontological security and trust without which ethnocultural identity is impossible. Every person is rooted in the everyday time and space flow, in the life cycle, in the stream of institutional time, in the supra-individual structuring of social institutions. Ethnocultural identity is a certain horizon which can be treated by the individual in a different way, but abandonment of this horizon is not possible. In these 
terms ethnocultural identity is a characteristic of a person's attitude to himself, his "selfaffiliation", on the one hand, and a person's belonging to a certain ethno-social community, on the other hand (Heffe et al, 2009).

It should be noted that symbolic interactionism shifts the accent to the question of how the individual's ethnocultural identity is formed in the course of social interaction and how it is represented in the surrounding world, with the preservation of uniqueness and singularity of the individual's personality.

It should be emphasised that the positive message of Mead's (1972) concept captured attention of many scholars engaged in the study of ethnocultural identity (e.g. De Vos \& Suarez-Orozco, 1990; Romanucci-Ross \& De Vos, 1995; Hsu, 1983; Habermas, 2004). Among the researchers dealing today with identity issues, in particular ethnocultural identity, a German philosopher and sociologist Jurgen Habermas, who presented the concept of "identity balance" (Habermas, 1999), should be mentioned.

Habermas proposes to use the term "Self-identity" as an aggregate of personal and social identities which are viewed by him as two dimensions: the notion of balancing "selfidentity" is realised in them. The personal and social identities are correlated as a vertical and horizontal dimension, where the vertical (personal identity) is in charge of coherence of a person's life history, while the horizontal (social identity) provides a possibility to meet various requirements in the role-playing systems to which a person belongs. The individual's "self-identity" arises within a balance between personal and social identities. The establishment and maintenance of this balance takes place in a system of certain social relations with the help of interaction techniques among which language is of exclusive importance. A person manifests his identity in interpersonal communication by seeking to meet the normative expectations of the interaction partner. At the same time, the individual seeks to express his uniqueness (Habermas, 1976).

According to Habermas, the essential characteristic of interpersonal communication is primarily represented by mutual understanding. It is the accent on reaching mutual understanding between different social actors that is viewed by the scholar as the fundamental difference between communicative action and all other types of social action. According to Habermas, a genuine communicative action is a real mechanism for maintaining mutual understanding as the main factor of solidarity and stability in the society. These ideas acquire special significance in modern sociocultural conditions, when one of the global challenges is the problem of mutual understanding between people, establishment of a dialogue of different cultures: "The norms which often are recognised by many citizens and officials only rhetorically are gradually transformed into internal beliefs through participation in discussions and enforcement of new legal standards. The same way nation-states learn to perceive themselves as members of larger political communities" (Habermas, 2004).

Proceeding from the above, Habermas believes that one's ability and opportunity to identify himself with a particular social group is an essential condition of his ethnocultural 
identity. Thus, ethnocultural identity is a milieu in which personal reflection and intersubjective recognition overlap, which reflects the substance of true ethnocultural identity. Referring to Georg W. F. Hegel's dialectic, Habermas notes a paradoxical feature of ethnocultural identity: absolute individualisation and absolute generality as two significant aspects in terms of conceptualisation of one's self, which should be perceived abstractly and at the same time holistically. Habermas associates the establishment of ethnocultural identity with the formation of industrial society, considering national consciousness to be a way towards cultural integration as a specific feature of the New Age (Habermas, 2001). Exploring possible environments for "self-identity" formation in complex societies, Habermas concludes that the orientation at the European culture as a standard of universal human values and as a basic foundation of "self-identity", including ethnocultural identity, proved to be a failure at the end of the eighteenth century, leading to the idea of plural identities, their fundamental incompatibility with each other and impossibility of a dialogue on equal footing. The establishment of capitalist society in the nineteenth century is characterised by shifting the emphasis in the interpretation of the ethnocultural identity concept towards legal framework. The specific identity is conditioned by the particularity of legal norms; a person identifies himself, in the first place, as a citizen entitled with a certain set of individual freedoms (Skorodumova, 2010). People's ties with their historical homeland weaken with the development of industrial society and the transition to post-industrial society. At that period, the theme of estrangement, including from one's ethnocultural identity, becomes one of the main subjects in the philosophy of Freudism, existentialism, Marxism, etc. The development and spread of mass culture leads to the idea of formation of a certain common mentality which emerges "out of identification with consciously accepted traditions of a particular politico-cultural society" (Habermas, 2001).

Habermas believes that the most reasonable substantiation of the above is the so-called universal identity which will make it possible to withdraw from state-, national-, partisanand other types of identity as historically obsolete. Moreover, the political practice of the democratic state does not allow for any privileged ethnocultural form of living in a social state (Parhomenko, 2014).

The new universal identity, which has a supranational character, represents a continuous process of learning and at the same time the awareness of citizens' equal chances to participate in it, this reflecting its collectivist substance, which makes it possible to talk of immersiveness (Habermas, 1999; Habermas, 2004). Thus, the universal identity is determined by the peculiarities of communication process, which ultimately leads to the situation when the communication process actor determines his "nationality" himself.

In this regard, Habermas' idea that the emergence of the "global citizen" status is quite possible seems to be noteworthy, since the contours of global citizenship have been already outlined to a significant extent. In his view, global citizens will be able to get organised globally and create a democratically elected government in the future. Moreover, the normative cohesion of world citizens will be based on understanding of the 
moral and legal framework of the society. This means that the regulatory boundaries of the cosmopolitan society are set only by the legal norms of moral nature, "moral universalism" of the global citizen's rights.

Habermas' appeal to the search of universal identity as a certain universal basis capable to consolidate the fragmented society is quite understandable. Habermas, considering the crisis of partisan identity on a global scale, notes the failure of the state to consolidate the society as well as the absence of institutes in the modern world capable of ensuring mutual understanding and integration of social subjects. Nevertheless, according to some researchers (Parhomenko, 2014), formation of a universal global civic identity is a utopia for several reasons. First, the world community is something abstract, and it is quite difficult to outline its universal values. Second, citizenship is a special reality which is associated with a certain territory and state; therefore, imparting a universal character to it, Habermas, though resolving the contradiction between the universal "Self-identity" and the collective identity, deprives it of the institutional character (Habermas, 2004).

It should be noted, with respect to the problem of the given research, that the nature and content of ethnocultural identity are distinguished by dynamics and multiplicity, especially in composite societies; however, Habermas mentions some common feature: "The society has an identity ascribed to it not in the trivial sense as an object may have: the latter can be identified by different observers as the same object, even if they perceive it and describe it in a different way. The society generates its identity in a certain way, and the fact that it does not lose its identity is due to its own efforts" (Habermas, 1999).

\section{Conclusions}

Generalising the views of representatives of symbolic interactionism considering the problem of ethnocultural identity, it should be emphasised that this area is distinguished by profound analysis of the ethnocultural identity phenomenon and the ways of its formation. The scholars have identified the notions of perceived and unconscious identity, dependence of identification on social space and time and the system of social institutes. By changing the paradigm of exploring the human personality and making it closer to the personality analysis in a social context, the representatives of symbolic interactionism open a perspective in the study of ethnocultural identity: organic interaction of the sociocultural environment and the individuum. They showed that the emanation of culture and of individual "Self" takes place in the recurrent process of people's social interaction. The individual fathers himself in the process of interaction with other people. The formation of ethnocultural identity is possible only in community with others and as a result of incessant interaction. The research studies of the representatives of symbolic interactionism are distinguished by the spirit of activity and comprehension of significant role of man as a proactive subject of his vital activity.

The problem of ethnocultural identity acquires particular relevance in the epoch of globalisation, when the differences between nations and ethno-social groups are erased, along with ignoring the folk traditions, customs, rites, i.e. the historically and culturally 
established values that distinguish one nation from another, on the one hand, and that enrich the multinational culture of their country, on the other hand.

One of the key conditions for the formation of ethnocultural identity is assimilation of values, norms, beliefs of "own" socio-cultural community, which is possible in the process of social interaction, meaningful communication in terms of symbolic interactionism, on the condition of maintaining the uniqueness and singularity of the individual's personality.

\section{Acknowledgements}

This article was implemented within the framework of the grant of the President of the Russian Federation for state support of young scientists MK-2349.2020.6.

\section{Bibliographic references}

Adams, G. \& Markus, H. R. (2001). Culture as patterns: An alternative approach to the problem of reification. Culture \& Psychology, 7, $283-296$, https://doi.org/10.1177/1354067X0173002

Andreeva, G.M., Bogomolova, N.N., \& Petrovskaya, L.A. (2002). Foreign Social Psychology of the 20th Century: Theoretical Approaches. Moscow: Aspect Press.

Arbeláez-Campillo, D., Tatsiy, V., Rojas-Bahamón, M., \& Danilyan, O. (2020). Contributions of critical thinking as a form of participation and political deliberation. Amazonia Investiga, 9(27), 5-12. https://doi.org/10.34069/Al/2020.27.03.1

Arutyunyan, S. (2010). The Problem of Identity in Psychology. Bulletin of the Yerevan University. Philosophy, Psychology, (4), 68-82. Retrieved from: http://www.ysu.am/files/07S_Harutyunyan.pdf (in Russian)

Cast, A.D., \& Burke, P.J. (2002). A Theory of Self-Esteem. Social Forces, 80(3), 1041-1068. https://doi.org/10.1353/sof.2002.0003

Cooley, C.H. (1907). Social Consciousness. Proceedings of the American Sociological Society, 1, 97-109

Cooley, C.H. (1909). Social Organization: A study of the larger mind. New York: Charles Scribner's Sons.

Cooley, C.H. (1922). Human Nature and the Social Order. New York: Charles Scribner's Sons.

De Vos, G., \& Suarez-Orozco, M. (1990). Status Inequality: The Self in Culture. Thousand Oaks: SAGE Publications

Eng, S. \& Tram, J. (2021). The Influence of Family and Community Factors on Ethnic Identity. Journal of Multicultural Counseling and Development, 49, 32-44. 10.1002/jmcd.12204.

Goffman, E. (1959). The Presentation of Self in Everyday Life. Norwell: Anchor.

Goffman, E. (1961). Asylums: Essays on the Social Situation of Mental Patients and Other Inmates. New York: Doubleday.

Goffman, E. (1963). Stigma: Notes on the Management of Spoiled Identity. London: Penguin. 
Habermas, J. (1971). Toward a Rational Society: Student Protest, Science, and Politics. Boston: Beacon Press

Habermas, J. (1976). Identitat. Zur Reconstruction des historischen Materialisnius. Frankfurt am Main: Suhrkamp Verlag.

Habermas, J. (1999). In search of national identity. Philosophical and Political Articles. Donetsk: Donbass (in Russian).

Habermas, J. (2001). Communicative action and detranscendentalized reason. Stuttgart: Reclam Verlag.

Habermas, J. (2004). The divided west. Small Political Papers. (3rd edition). Frankfurt am Main: Suhrkamp Verlag.

Hakim-Larson, J. and Menna, R. (2016). Acculturation and Enculturation: Ethnic Identity Socialisation Processes. Handbook of Arab American Psychology, 34-47. https://scholar.uwindsor.ca/psychologypub/51

Heffe, O., Malakhov, V., \& Filatov, V. (2009). Modern Western Philosophy. Encyclopedic Dictionary. Moscow: Cultural Revolution.

Hsu, F.L.K. (1983). Rugged Individualism Reconsidered: Essays in Psychological Anthropology. Knoxville: The University of Tennessee Press.

James, W. (1920). Collected Essays and Reviews. NY: Cornell University Library.

Katartzi, E. (2018). Unpacking Young People's National Identities: The Role of Ethnocultural and Religious Allegiances, History and "Others". Young, 26, 3, 215-231.

Markus, H. R. \& Kitayama, S. (1991). Culture and self: Implications for cognition, emotion, and motivation. Psychological Review, 98, 224-253. https://doi.org/10.1037/0033295X.98.2.224

Mead, G.H. (1972). Mind, self, and society: from the Standpoint of a social behaviorist. Chicago; London: The University of Chicago Press.

Parhomenko, R.N. (2014). Citizenship and national identity in the understanding of J. Habermas. Law and Politics, (3), 379-386. https://doi.org/10.7256/18119018.2014.3.7797

Rojas-Bahamón, M.J., Aguilar-Cruz, P.J., \& Arbeláez-Campillo, D.F. (2020). Curricular integration as a strategy to strengthen the educational process in public institutions in COVID-19 times. Revista Inclusiones, 7 (num Especial), pp. 233-241.

Romanucci-Ross, L. \& De Vos, G. (1995). Ethnic Identity: Creation, Conflict, and Accommodation (3rd Edition). Lanham: AltaMira Press.

Shamionov, R.M. (2014). Ethnocultural Factors of Person's Subjective Well-Being. $\begin{array}{llll}\text { Psychological Journal, } & 35, & 4, & 68-81 .\end{array}$ http://psystudy.ru/index.php/num/2018v11n60/1602-shamionov60.html

Shastina, E.M., Shatunova, O.V., \& Bozhkova, G.N. (2018). The Importance of Family Reading in Preservation of Ethno-Cultural Identity. Scientific Dialogue, (8), 304-315. (in Russian) https://doi.org/10.24224/2227-1295-2018-8-304-315

Skorodumova, O.B. (2010). National and Cultural Identity in Russia under Conditions of Information Society Formation. Anxiety, (4). Retrieved from: http://www.zpujournal.ru/e-zpu/2010/4/Skorodumova/ (in Russian).

Tancheva, I.V. (2017). Ethnocultural Identity of the Subject. Ethnocultural Education in the Modern World, 733-737 (in Russian). 